
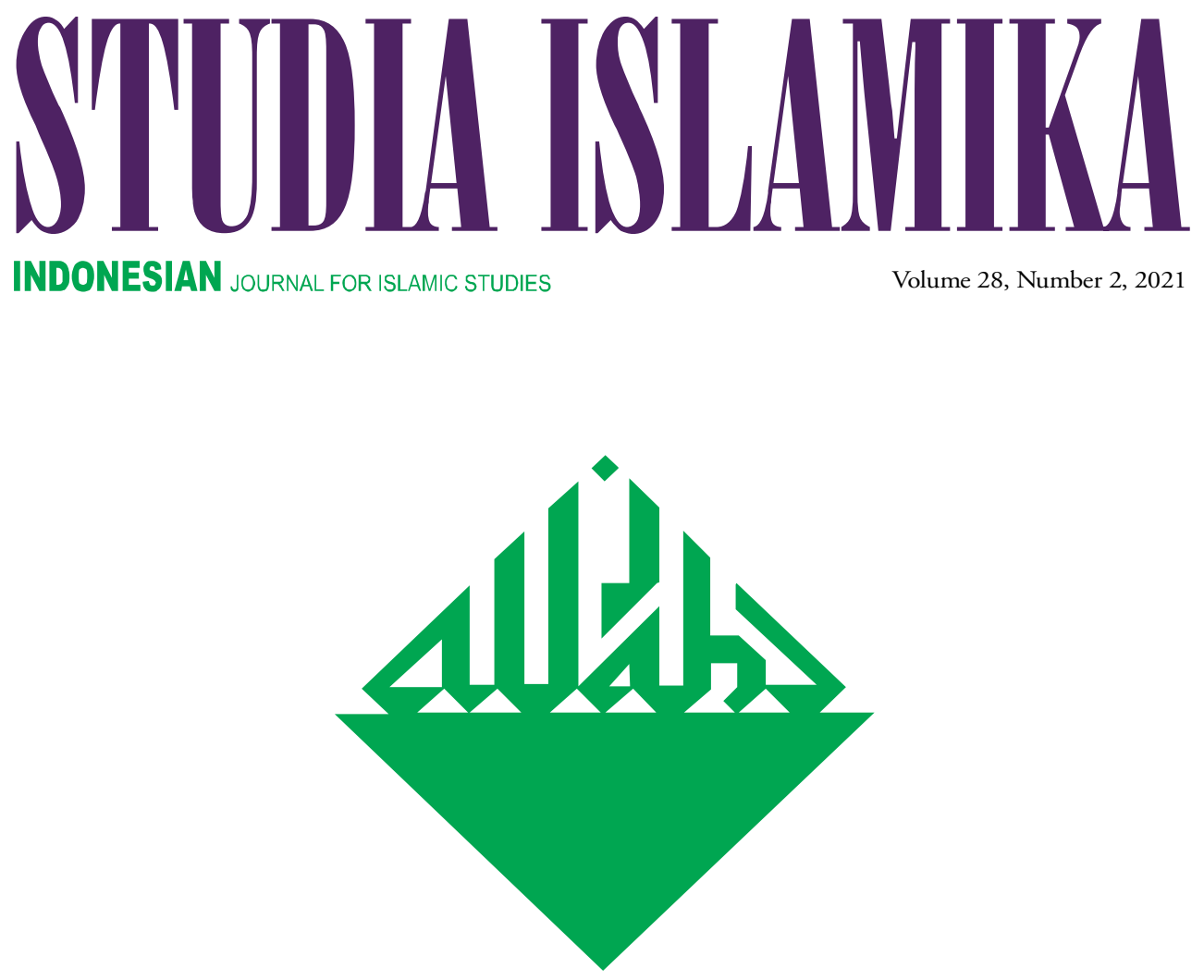

The Word 'Lebai' and Its Ethnic Origins:

Reassessing an EARly Designation for Muslim Religious Officials in the Malay World

Alexander Wain

FORBIDDEN VISIBILITY:

Queer Activism, Shari'a Sphere

and Politics of Sexuality in Aceh

Moch. Nur Ichwan

The Politics of Syariatisation in Indonesia:

MMI and GARIS' Struggle for Islamic LaW

Ratno Lukito 
STIUDLA ISLAMIIIKA 



\section{STIDIIA ISLAVIIIKA}

Indonesian Journal for Islamic Studies

Vol. 28, no. 2, 2021

EDITOR-IN-CHIEF

Azyumardi Azra

MANAGING EDITOR

Oman Fathurahman

EDITORS

Saiful Mujani

Jambari

Didin Syafruddin

Jajat Burhanudin

Fuad Jabali

Ali Munhanif

Saiful Umam

Dadi Darmadi

Jajang Jahroni

Din Wahid

Euis Nurlaelawati

INTERNATIONAL EDITORIAL BOARD

M. Quraish Shihab (Syarif Hidayatullah State Islamic University of Jakarta, INDONESIA)

Martin van Bruinessen (Utrecht University, NETHERLANDS)

John R. Bowen (Washington University, USA)

M. Kamal Hasan (International Islamic University, MALAYSIA)

Virginia M. Hooker (Australian National University, AUSTRALIA)

Edwin P. Wieringa (Universität zu Köln, GERMANY)

Robert W. Hefner (Boston University, USA)

Rémy Madinier (Centre national de la recherche scientifique (CNRS), FRANCE)

R. Michael Feener (National University of Singapore, SINGAPORE)

Michael F. Laffan (Princeton University, USA)

Minako Sakai (The University of New South Wales, AUSTRALIA)

Annabel Teh Gallop (The British Library, UK)

Syafaatun Almirzanah (Sunan Kalijaga State Islamic University of Yogyakarta, INDONESIA)

ASSISTANT TO THE EDITORS

Testriono

Muhammad Nida' Fadlan

Rangga Eka Saputra

Abdullah Maulani

ENGLISH LANGUAGE ADVISOR

Benjamin J. Freeman

Daniel Peterson

Batool Moussa

ARABIC LANGUAGE ADVISOR

Tb. Ade Asnawi

Ahmadi Usman

\section{COVER DESIGNER}

S. Prinka 
STUDIA ISLAMIKA (ISSN 0215-0492; E-ISSN: 2355-6145) is an international journal published by the Center for the Study of Islam and Society (PPIM) Syarif Hidayatullah State Islamic University of Jakarta, INDONESIA. It specializes in Indonesian Islamic studies in particular, and Southeast Asian Islamic studies in general, and is intended to communicate original researches and current issues on the subject. This journal warmly welcomes contributions from scholars of related disciplines. All submitted papers are subject to double-blind review process.

STUDIA ISLAMIKA has been accredited by The Ministry of Research, Technology, and Higher Education, Republic of Indonesia as an academic journal (Decree No. 32a/E/KPT/2017).

STUDIA ISLAMIKA has become a CrossRef Member since year 2014. Therefore, all articles published by STUDIA ISLAMIKA will have unique Digital Object Identifier (DOI) number.

STUDIA ISLAMIKA is indexed in Scopus since 30 May 2015.

Editorial Office:

STUDIA ISLAMIKA, Gedung Pusat Pengkajian

Islam dan Masyarakat (PPIM) UIN Jakarta,

Jl. Kertamukti No. 5, Pisangan Barat, Cirendeu,

Ciputat 15419, Jakarta, Indonesia.

Phone: (62-21) 7423543, 7499272, Fax: (62-21) 7408633;

E-mail: studia.islamika@uinjkt.ac.id

Website: http://journal.uinjkt.ac.id/index.php/studia-islamika

Annual subscription rates from outside Indonesia, institution: US\$ 75,00 and the cost of a single copy is US\$ 25,00; individual: US\$ 50,00 and the cost of a single copy is US\$ 20,00 . Rates do not include international postage and handling.

Please make all payment through bank transfer to: PPIM, Bank Mandiri KCP Tangerang Graha Karnos, Indonesia, account No. 101-00-0514550-1 (USD),

Swift Code: bmriidja

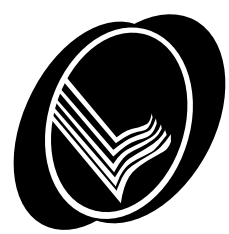

Harga berlangganan di Indonesia untuk satu tahun, lembaga: Rp. 150.000,-, harga satu edisi Rp. 50.000,-; individu: Rp. 100.000,-, harga satu edisi Rp. 40.000,-. Harga belum termasuk ongkos kirim.

Pembayaran melalui PPIM, Bank Mandiri KCP Tangerang Graha Karnos, No. Rek: 128-00-0105080-3 


\section{Table of Contents}

\section{Articles}

253 Alexander Wain

The Word 'Lebai' and Its Ethnic Origins:

Reassessing an Early Designation

for Muslim Religious Officials in the Malay World

283 Moch. Nur Ichwan

Forbidden Visibility:

Queer Activism, Shari'a Sphere

and Politics of Sexuality in Aceh

319 Ratno Lukito

The Politics of Syariatisation in Indonesia:

MMI and GARIS' Struggle for Islamic Law

349 David Efendi, Nanang Indra Kurniawan, Purwo Santoso From Fiqh to Political Advocacy:

Muhammadiyah's Ecological Movement in the Post New Order Indonesia

385 Bambang Qomaruzzaman, Busro Doing Hijrah through Music: A Religious Phenomenon Among Indonesian Musician Community 
413 Muhammad Napis Djuaeni \& Ahmadi Usman

Al-Lughah al-'Arabiyah

fī al-ma'āhid al-Islāmīyah bī Indūnīsīyā:

Mushkilātuhā wa țuruq hallihā

\section{Book Review}

457 Yanwar Pribadi

Kebangkitan Konservatisme Islam:

Politik Identitas dan Potret Demokrasi di Indonesia

\section{Document}

473 Fahmi Imam Fauzy \& Aptiani Nur Jannah Islamic on Screen:

Religious Narrative on Indonesia's Television 


\title{
Alexander Wain
}

\section{The Word 'Lebai' and Its Ethnic Origins: Reassessing an Early Designation for Muslim Religious Officials in the Malay World}

\begin{abstract}
This article proposes a new etymon for the Malay word lebai (minor religious officiallscholar), namely the Sino-Muslim term libai (禮拜, worship or religious service conducted in a mosque). Scholars have traditionally argued that lebai, a loanword introduced during the early stages of Islamization, derives from the Tamil leppai (or lebbai), likewise signifying (amongst other things) a minor religious official/scholar. On this basis, it has been argued that Tamil Muslims acted as Southeast Asia's earliest Islamic officials. This article critically reassesses the evidence underlying this attribution. By tracing the earliest known Malay usage of lebai to Java -where it emerged alongside SinoMuslim influences associated with Cirebon, Gresik and Demak- the etymon libai is proposed: since the Song dynasty (960-1279), Sino-Muslims have used the noun libai as a designate for religious affairs (particularly prayers) conducted in a mosque. This study suggests that lebai originates with this term, making it indicative of Sino-Muslim influence during Java's Islamization.
\end{abstract}

Keywords: Southeast Asian Islamization, Lebai, Malay Language, Java, Islam in China. 
Abstrak: Artikel ini mengusulkan etimon baru untuk sebuah kata dalam bahasa Melayu, lebai (pegawai urusan keagamaan/ulama lokal), yaitu berasal dari istilah Sino-Muslim, libai (禮拜, ibadah atau pelayanan keagamaan yang dilakukan di masjid). Para sarjana umumnya berpendapat bahwa lebai, kata serapan yang diperkenalkan pada masa awal Islamisasi, berasal dari bahasa Tamil, leppai (atau lebbai), yang juga berarti seorang pegawai agamal ulama. Atas dasar ini, mereka berargumen bahwa Muslim Tamil berperan sebagai pegawai urusan agama Islam paling awal di Asia Tenggara. Artikel ini secara kritis menguji kembali bukti yang mendasari argumen tersebut. Melalui penelusuran penggunaan bahasa Melayu paling awal yang diketahui terhadap kata lebai di Jawa - di mana ia muncul bersamaan dengan pengaruh Sino-Muslim di Cirebon, Gresik dan Demak- etimon libai diajukan: sejak dinasti Song (960-1279), Sino-Muslim telah menggunakan kata benda libai sebagai sebutan untuk urusan keagamaan (khususnya salat) yang dilakukan di masjid. Studi ini mengusulkan bahwa lebai berasal dari istilah ini, yang menunjukkan pengaruh Sino-Muslim selama Islamisasi Jawa.

Kata kunci: Islamisasi Asia Tenggara, Lebai, Bahasa Melayu, Jawa, Islam di China.

ملخص: تقترح هذه المقالة مصدرا جديدا لكلمة "lebai الملايوية التي تعني مسؤول

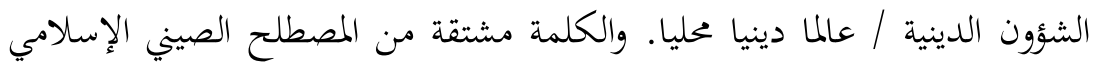
《libai»

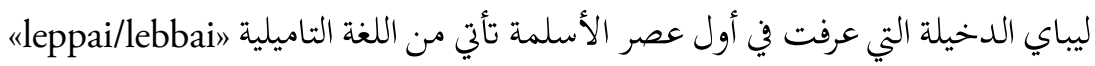

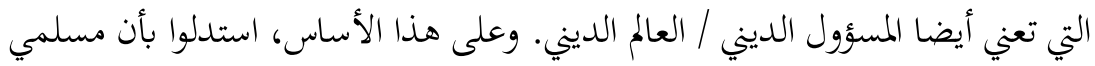

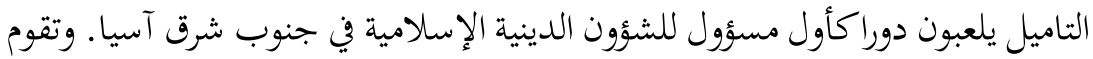

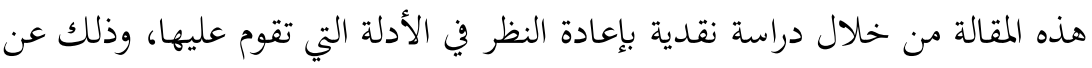

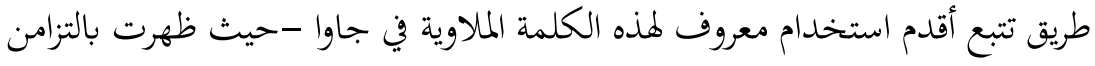

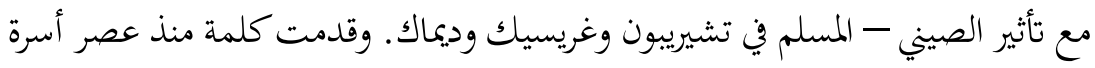
سونغ ( IV9

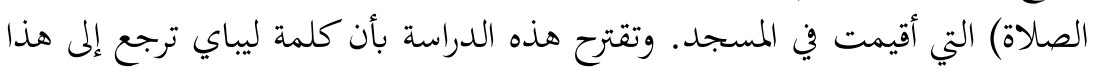
المصطلح الذي يشير إلى تأثير الصيني الإسلامي أثناء أسلمة جاوا.

الكلمات المفتاحية: أسلمة جنوب شرق آسيا، ليباي، اللغة الملايوية، جاوا، الإسلام في الصين. 
W ithin the broad expanse of Southeast Asian history, few subjects have garnered as much attention as the Islamization of the Malay Archipelago. From the early twentieth century, several explorations of this event have sought to position Tamil Muslims at its heart. Within that context, the etymology of the Malay term lebai (also spelt labai or lebe) has proven crucial. Signifying a minor religious official/scholar responsible for conducting religious affairs (including worship) in a mosque, lebai has been linked to the Tamil leppai (or lebbai), likewise signifying a minor religious official/scholar, in addition to a merchant, jeweller, or member of an endogamous Tamil Muslim community from northern Tamil Nadu. Beginning with Van Ronkel (1914), this conclusion has served to identify Tamil Muslims as the earliest Islamic officials/scholars in Southeast Asia. In this article, however, we propose a radically new etymon: the Chinese noun libai (禮拜). From the Song period (960-1279) onwards Sino-Muslims ${ }^{1}$ have used libai to designate "worship" or a "religious service" conducted in a mosque. If indeed linked to this term, the Malay lebai becomes indicative not of Tamil, but of Sino-Muslim influence over Southeast Asia's early Islamization.

Our article begins with an outline of those arguments postulating a Tamil etymon for lebai. Re-assessing the evidence underpinning those studies, notably indications of the term being used in Malay 130 years before it emerges in Tamil, we suggest that this etymology be reversedthat lebai be interpreted as the origin of leppai, not vice versa. The article then proceeds to identify the earliest known Southeast Asian attestations to lebai, establishing Java as its probable point of origin, where it emerged amidst extensive Sino-Muslim influence associated with the port cities of Cirebon, Gresik and Demak. On this basis, the Sino-Muslim etymon libai is proposed.

\section{The Tamils, Lebai and Southeast Asia's Islamization}

On January 23, 1907, eminent Dutch scholar C. Snouck Hurgronje delivered his inaugural lecture at Leiden University. Drawing upon his extensive knowledge of north Sumatra, home to Southeast Asia's earliest Islamic kingdoms, notably Samudera-Pasai (converted late thirteenth century), he sketched a preliminary portrait of the region's initial Islamization. Drawing attention to the late fourteenth- to early fifteenth-century Hikayat Raja Pasai, Samudera-Pasai's court chronicle, 
and one of Southeast Asia's earliest surviving Islamic texts, he noted its frequent references to Tamils. Set within the context of Southeast Asia's adherence to the Shafi' $\mathrm{i}$ madhhab, otherwise predominant only in South India and Yemen, and several instances of far-reaching cultural borrowings from the Tamil regions of India throughout Southeast Asia's pre-Islamic and Islamic periods (Kerlogue 2004, 69-97), Snouck Hurgronje argued that Tamil Muslims likely played a crucial role in the region's Islamization (G.W.J. Drewes 1968, 434; Hurgronje 1916, 53).

Snouck Hurgronje's academic stature ensured this hypothesis received considerable attention over succeeding decades, with several scholars offering additional insights designed to bolster its credibility. Amongst these was an observation made by Ph. S. van Ronkel (1914) regarding the origin of the Malay word lebai. Absent from all surviving pre-Islamic Malay written sources, and referring exclusively to minor Muslim religious officials/scholars responsible for performing acts of worship in a mosque, Van Ronkel argued that lebai was a loanword introduced into Malay during the early Islamic period-that is, somewhere between the late thirteenth and fifteenth centuries. ${ }^{2} \mathrm{He}$ further presumed its introduction occurred in close association with the region's first Muslim preachers. Significantly, therefore, Van Ronkel speculated that lebai originated with the Tamil leppai (also spelt lappai or labbai), variously used to denote a merchant, jeweller, ethnic grouping, or (as in Malay) minor Muslim religious official/scholar. Inspired by Snouck Hurgronje's preliminary conjectures, Van Ronkel suggested that leppai originally designated a Tamil Muslim merchant; such individuals had travelled to Southeast Asia along well-established trade routes, interacted with the local population, and thereby effected the first conversions. This proselytising role later entailed their metamorphization into the region's first religious officials, prompting the application of their originally mercantile honorific to all such functionaries (Ronkel 1914, 137-42). ${ }^{3}$

Successive scholars, as well as the Indonesian Etymological Project, have been content to both accept and perpetuate this etymology (Jones 2007). G. W. J. Drewes, for example, marshalled this derivation when tentatively tracing Southeast Asia's Islamization to the intervention of Shafi'i Tamil Muslims from Nagore, on the Coromandel Coast (G.W.J. Drewes 1968, 458-59). Yet other commentators, especially from Southeast Asia itself, being cognisant of T. W. Arnold's (mistaken) 
supposition that leppai is more appropriately interpreted as a Tamil corruption of 'arabi (Arnold 1927, 1), ${ }^{4}$ have construed lebai as being indicative of Arab-directed Islamization mediated through contact with South India. M. D. Mansoer, for example, undertook to establish this with regards to Samudera-Pasai, arguing that the (unsubstantiated, below) early use of lebai in north Sumatra suggested the presence of Arab trader-missionaries from South India at the point of Islamization (Mansoer 1963, 71).

Despite garnering such widespread acceptance, and notwithstanding additional evidence favoring Tamil involvement in Southeast Asia's Islamization, ${ }^{5}$ several problems underlie this etymology. Contrary to Van Ronkel's supposition, it is uncertain whether the Tamil leppai originally designated a Muslim merchant; its earliest attestation occurs in an untitled poem dated 1648, where it is applied to an Islamic religious official. Only from the late seventeenth century does the term emerge amongst Tamil speakers (including in Southeast Asia) as an honorific for Tamil Muslim traders (Tschacher 2009, 52-53). ${ }^{6}$ Prior to this, the established Tamil designation for seafaring Muslim merchants from Tamil Nadu and Kerala was not leppai but marakkayar, derived from the Arabic markab (boat) (Singh 1998, 2204-5). This term appears on an eleventh-century Tamil inscription near Barus, northwest Sumatra, demonstrating its early use within a Southeast Asian context (Subbarayalu 1998). By contrast, no early Malay inscription or text utilizes either leppai or lebai as a designation for Tamil Muslim traders. Rather, they refer to such individuals as keling (or kling), a term derived from 'Kalinga', the name of a pre-modern Indian state in what is today Odisha, in the Bay of Bengal (T. G. Hoogervorst 2015a, 64; Jones 1999, 105). Additionally, several thirteenth- to fifteenth-century batu Aceh (Muslim grave markers) associated with Samudera-Pasai style Tamil Muslim traders nayna, an appellation apparently derived from the Tamil nayanar, meaning "lord," "master," "God" or "Siva" (Lambourn 2004, 19). ${ }^{7}$ Culia constituted a more generic Malay term for Muslim merchants from South India over this period (T. G. Hoogervorst 2015b, 251).

In sum, this renders Van Ronkel's hypothesis hard to sustain; the surviving evidence does not establish "Tamil Muslim trader" as the original designation of either leppai or lebai, from which a Malay appellation for religious officials/scholars could have evolved. Moreover, 
as briefly noted, the earliest Tamil attestations to leppai are midseventeenth century. As demonstrated in the next section, the earliest known attestation to lebai amongst Malay speakers occurs between 1512 and 1515, more than 130 years earlier. This is suggestive: if lebai predates the appearance of leppai by more than a century, plausibly (if the two terms are indeed related) the former constitutes the source of the latter, not vice versa. Indeed, many Tamil specialists have taken precisely this stance.

Notwithstanding some recent exceptions (Feener 2009), scholars of Southeast Asia have traditionally assumed South India influenced Southeast Asia far more profoundly than vice versa. Tamil specialists, however, have endeavored to paint a more balanced picture. Ethnologist and Tamil specialist E. Thurston, for example, who employed leppai as an ethnonym applicable to a subgroup of the marakkayar, ${ }^{8}$ observed that centuries of interaction with the Straits of Melaka had occasioned the adoption of various Malay cultural facets amongst the leppai. This included an ability to converse in Malay, with Thurston isolating several Malay-to-Tamil linguistic borrowings (Thurston and Rangachari 1909, 199-200). Furthermore, other scholars have identified Malay involvement in the formation of Tamil Islamic culture. For example, several scholars have attributed the late sixteenth-century development of arwi (Tamil in the Arabic script) to Malay intervention. They have observed that Arwi and Jawi (Malay in the Arabic script) employ similarly modified Arabic characters to represent shared sounds absent in Arabic. For example, both systems utilize the Arabic $f a$ (ف) to represent $p$, with the addition of two upper dots in Jawi (ث) and one lower dot in arwi (ب); 'ayn (ع) to represent $n g$, with three upper dots in Jawi (₹) and three lower dots in arwi (๕); and nun (ن) to represent nya, with two additional upper dots in Jawi (ن) and two additional lower dots in arwi (ب) (T. G. Hoogervorst 2015b, 256; Ricci 2011, 98; Tschacher 2001, 27). Given Jawi developed during the early fourteenth century (Musa, 2003), almost two centuries before arwi, these similarities, if indeed evidence of borrowing, suggest the latter evolved in conversation with Southeast Asian Islamic scholarship, not vice versa.

Even though discussions of these and other commonalities (including adherence to the Shafi'i madhhab and a shared Suf praxis) have tended to prioritize Tamil agency, neglecting consideration of how Southeast Asia could have shaped Tamil Islam, the potentiality for the latter is clear. 
Over the sixteenth and seventeenth centuries, the rapid commercial expansion of the powerful and fiercely Islamic sultanate of Aceh, then Southeast Asia's pre-eminent center of Malay culture and Islamic scholarship, facilitated extensive interaction between north Sumatra and India (Andaya 2016, 108; Boxer 1969). Within that context, Tamil Sufi texts began describing Southeast Asia as the location where Sufi gurus must travel to complete their training (Bayly 1989, 147-48). Over the seventeenth century, the Dutch also began to exile politically active Southeast Asian Muslim scholars to Sri Lanka, where they interacted with Tamil and other Indian Muslims. Most notable amongst these exiles was the famed scholar, Muhammad Yusuf al-Maqassari (1626-1699). Exiled to Sri Lanka in 1684, al-Maqassari spent a decade preaching to his fellow Malay exiles, in addition to the local (Tamil) Muslim population. During that period, al-Maqassari was able to influence (and be influenced by) his Indian contemporaries, including scholars like Sidi Matilaya, Abu al-Ma'ani Ibrahim Minhan and 'Abd al-Siddiq b. Muhammad Sadiq. His famed Safinat al-naja, for example, was written at the behest of Ibrahim Minhan. This process of shared interaction was further reinforced by the contemporary transmission of Malay religious texts to Sri Lanka; Malay pilgrims travelling to and from the Haramayn, drawn by alMaqassari's presence, brought important Southeast Asian works to the island, including texts by Nur al-Din al-Raniri (d.1658) and 'Abd al-Rauf al-Singkili (d.1693). These helped inform the type of Islam practiced among the Tamils (Armstrong 2020; Azra 2004, 98-99).

Within this context, and given lebai appears in Malay more than 130 years prior to leppais initial utilization in Tamil, plausibly the latter originates with the former. Certainly, as argued by J. More, were the opposite true, lebai's static frame of reference in comparison to leppais more malleable application would constitute a source of confusion. If the Tamil leppai were the source of the Malay lebai, the observer might reasonably expect more than one of its applications to have travelled into Malay, which is not the case. But, as More highlights, pre-modern Tamils travelling in search of religious knowledge often engaged in trade or worked as craftsmen to finance their passage (More 2004, 20 22). Under those circumstances, a religious honorific gained either in Southeast Asia or amongst exiled Southeast Asian scholars in Sri Lanka could, once brought back to Tamil Nadu, have acquired the additional sense of a merchant or jeweller. 
But, if we therefore reject a Tamil origin for lebai, from where else could this Malay term have originated? As discussed, lebais absence from all known pre-Islamic Malay sources, coupled with its narrow application, suggests it constitutes a loanword introduced during Islamization. The above conclusions do not alter this supposition. The term has no obvious origin, however, in any major Islamic language, including Arabic, Persian, Turkish or Urdu. Consideration of the term's earliest Malay attestation, however, indicates a possible Chinese source.

\section{The Earliest Malay Attestations to Lebai}

Although few Malay manuscripts pre-date the nineteenth century, rendering any judgements about early Malay lexical usage provisional, a sufficiency of source material survives to allow a tentative reconstruction of lebais dissemination through the region. In addition to pre-eigteenth-century Malay manuscripts, this evidence includes a number of inscriptions, later manuscript versions of texts rooted in the fourteenth to seventeenth centuries, and a range of early European and Chinese sources that-however rudimentarily_inform us about Malay lexical matters. ${ }^{?}$

As discussed, Van Ronkel's proposed etymology has perpetuated the largely unexamined assumption that lebai entered Southeast Asia via north Sumatra (that is, at a point geographically adjacent to the Indian Ocean), from whence it presumably travelled to the Straits of Melaka, towards Java and the rest of the region. A close examination of the surviving evidence, however, refutes this reconstruction. Rather, the earliest known occurrence of lebai is not found in association with north Sumatra, but Java. In the Suma Oriental of Portuguese apothecary, Tomé Pires (written 1512 to 1515), we find the following statement concerning the Javanese entrepôt of Cirebon:

The land of Cherimon [Cirebon] is next to Sunda; its lord is called Lebe Uça [Lebai Isa?]. He is a vassal of Pate Rodim [Raden Patah], lord of Demak...About forty years ago [i.e. 1472-5] this place Cherimon was heathen, and the [first] lord of Demak at that time had a slave from Grisee [Gresik], and he made the said slave a captain against Cherimon, and this his slave from Grisee who was lord of Cherimon is grandfather of this Pate Rodim who is lord of Demak today. (Pires 2005, 183)

Although this constitutes the sole occurrence of lebai within the Suma Oriental, it firmly establishes that term as a personal title applicable to 
a prominent Muslim resident of Java's northern coast over the period 1512-1515, more than 130 years prior to leppais first appearance in Tamil. That it is applied to a political figure need not prove discordant with our accepted definition of lebai; many early Javanese Muslim rulers also constituted prominent religious leaders (Rinkes 1996; A. Wain 2017, 425-28).

Concerning the extent of lebais utilization across sixteenth-century Java, although Malay constituted a lingua franca among entrepôts like Cirebon, early Islamic texts associated with those locations are both scarce and predominantly written in Old Javanese, from which language lebai is absent (Zoetmulder and Robson 1982). ${ }^{10}$ The term also fails to appear in association with Java's earliest Islamic (and predominantly Arabic-language) funerary inscriptions (Yatim and Nasir 2007, 3338). The island's earliest surviving Malay-language Islamic chronicle, however, the seventeenth-century Hikayat Hasanuddin (from Banten, west Java), does utilize lebai as a generic label for religious scholars. At the beginning of the text, for example, the Muslim scholars of Pakuan, a small principality near Banten, are collectively designated lebai-lebai (Edel 1938, 30). But, regardless of whether lebai was used widely or restrictively across early sixteenth-century Java, the Suma Oriental evidently establishes its presence on that island during that period. Elsewhere in the region, lebai does not appear until considerably later.

With regards to north Sumatra, lebais oft-assumed point of entry into the region, no trace of that term emerges until the turn of the seventeenth century, prior to which a preference for Arabic nomenclature predominates. For instance, the earliest surviving examples of north Sumatran Islamic titular are found in association with batu Aceh produced for residents of Samudera-Pasai. Dating from the thirteenth to fifteenth centuries, these artefacts, all located near modern-day Lhokseumawe, are inscribed almost exclusively in Arabic. While this necessitates a penchant for Arabic nomenclature (notably shaykh), several batu Aceh nevertheless bear non-Arabic titles, including nayna (above). None of the examples that have been read, however, carry lebai (Lambourn 2004, 2008). This observation holds across several other north Sumatran sites preserving gravestones of comparable age, including Lhok Lambaro (ancient Lamreh/Lamuri) (Montana 1997).

A preference for Arabic nomenclature is also apparent amongst all known early north Sumatran Islamic literary sources. The aforementioned 
Hikayat Raja Pasai, for example, Southeast Asia's earliest surviving Islamic court chronicle, styles its religious officials and scholars either shaykh or faqir (Jones 1999, 14-16). Nowhere does it utilize lebai. This also holds for the earliest known Malay translations of the Persian epic, Hikayat Amir Hamzah, episodes and themes from which inspired many sections of the Hikayat Raja Pasai, implying its presence in Southeast Asia prior to the latter's composition (A. S. Ahmad 1987). Lebai is also absent from the work of north Sumatra's famed mystic, Hamzah al-Fansuri (d.1527/ ca.1600) (Al-Attas 1970, 233-96; G.W.J. Drewes 1968).

Rather, the earliest known attestation to lebai within a north Sumatran context occurs in the Spraek en de Woord-Boek in de Maleysche en de Madagaskarsche Talen (Speech and Vocabulary of the Malay and Madagascar Languages), a Dutch-Malay-Madagascan vocabulary compiled by Frederick de Houtman in Aceh between 1599 and 1602 (first published in Amsterdam, 1603). ${ }^{11}$ Well-known for its idiosyncratic Malay spelling conventions, this text renders lebai as lebbêe within the first of its two wordlists (Lombard 1970, 209). Subsequently, lebai also appears in the Hikayat Aceh, a semi-mythical biography of Acehnese sultan, Iskandar Muda (r.1607-1636). Written between 1600 and 1625, this text uses lebai twice during a dispute between a young Iskandar Muda and one of his religious teachers, when the former exclaims: "Husyyari lebai, tahan baik-baik, kepala lebai hamba palu (Be alert teacher, guard well, or I will break your head)" (Iskandar 1995, 201). Subsequently, in 1644, an Acehnese delegation to colonial Batavia informed their Dutch hosts that their chief minister, previously designated shaykh al-Isläm, now bore the title Leubè Kita Kali (Andaya 2016, 131). By that point, usage of lebai appears to have been well-established in north Sumatra.

On Sumatra's west coast, examples of early Southeast Asian Muslim honorifics are found in association with five fourteenth- to early twentiethcentury grave assemblages at Bukit Hasang, the site of ancient Barus (converted late thirteenth to fourteenth century). Inscribed in both Arabic and Jawi, these artefacts include two pre-seventeenth-century examples bearing religious titles relevant to the current discussion. The earliest, dated 1397, bears the name "Shaykh Rukn al-Din Imam Khatib", thereby adding the Arabic imām (prayer leader) and khätib (preacher) to the already observed shaykh. The second, on the other hand, dated Sha'ban 4, 973 (February 24, 1566), is dedicated to "the faqi $i$ Makhdum Sayf al-Din 
bin Makhdum 'Ali'. As discussed below, the Arabic makhdūm (teacher of sunnah) also appears on the Malay Peninsula and likely indicates a Sufi connection mediated through either Central Asia or north India (Perret, Surachman, and Kalus 2017, 297, 329; Yatim and Nasir 2007,32-33). This notwithstanding, these west Sumatran gravestones reinforce an impression of a preference for Arabic nomenclature, with an accompanying failure to utilize lebai, as seen above.

A similar preference for Arabic titular accompanied by the absence of lebai characterizes the early textual legacy of the Malay Peninsula, formerly home to the Sultanate of Melaka, the fifteenth- to early sixteenth-century center of Malay Muslim culture. The UndangUndang Melaka (Laws of Melaka) and a Chinese-Malay vocabulary of 482 words, for example, each datable (at least in part) to the sultanate, fail to utilize lebai, preferring to draw their Islamic terminology from Arabic (Edwards and Blagden 1931; Fang 1976). This trend continues in Melaka's court chronicle, the Sejarah Melayu (or Sulālat al-salāțin), completed in Johor in 1612 but rooted in earlier material. This text consistently styles religious officials mawlāná (master). Mention is made, for example, of a Mawlana Abu Bakr under Sultan Mansur Shah (r.1459-1477) and a Mawlana Sada Jahan under Sultan Mahmud Shah (r.1488-1511) (Cheah 2010, 133, 183). This final individual is simultaneously accorded the Arabic title makhdum, an appellation the text likewise applies to an important Samudera-Pasai religious official, Tun Makhdum Mua (Cheah 2010, 183-84). As briefly mentioned, over this period mawlāná and makhdūm, although both Arabic, were favored Central Asian and north Indian terms for a Sufi shaykh, perhaps indicating influence from one or both of those regions (Majul 1999, 59). Indeed, the Sejarah Melayu evinces a particular curiosity in Central Asia, notably regarding ongoing disputes between its religious scholars (Cheah 2010, 249-50), while Sada Jahan is a Persianate name common to north India over this period. Aside from these terms, the Sejarah Melayu also refers to a qā $\bar{d}$ (judge) of Melaka (Cheah 2010, 185).

The Sejarah Melayu's tendency to style religious scholars mawlāná tallies well with another vocabulary from this period, the 426-word Malay-Italian lexicon compiled by Italian traveller, Antonio Pigafetta (d.ca.1531). First published in 1525 as an appendix to Pigafetta's account of Ferdinand Magellan's near circumnavigation of the world, aside from a scattering of Bruneian-Malay and (probably misplaced) 
Filipino words, this text draws exclusively from the "pure Malay" most closely associated with Melaka over this period (Bausani 1960, 239). ${ }^{12}$ Within that context, it becomes significant that entry 7 provides three Malay terms for the Italian preti (priest): maulana, catip and mudin (Bausani 1960, 233). These are Malay renderings of the Arabic terms mawlāná, khätib and mu'adhdhin (one appointed to make the call to prayer). Lebai, a potential substitute for all these titles, remains absent.

Aside from these early texts, three Persian works in Malay translation (added to the aforementioned Hikayat Amir Hamzah) also circulated through the Peninsula over this period: Hikayat Muhammad Hanafiyah, Hikayat Iskandar Zulkarnain and Hikayat Bayan Budiman. Concerning the first two, although only later manuscript versions survive, none utilize lebai (Brakel 1977; Hussain 1986). Determining whether early versions of the Hikayat Bayan Budiman included lebai, however, is more problematic. In its most widely disseminated form, dating from the eighteenth to nineteenth centuries, the Hikayat Bayan Budiman comprises a collection of twenty-four disparate tales united around a shared narrative frame involving a wise parrot. Twelve of these stories derive directly from the text's Persian prototype, the Tuti-nama of Nakhshabi (written 1330), while a further four relate to other Persian antecedents. The remaining eight are original Malay constructions (Braginsky 2004, 419; Guillot 2004, 179). The most widely referred to published version of the Hikayat Bayan Budiman, comprising an amalgam of two mid-nineteenth-century manuscripts, utilizes lebai twice within its nineteenth story, concerning Khoja Astor and his Ethiopian slave, Habsyi (Winstedt 1966, 183-84). This tale is a Malay creation, absent from the text's Persian antecedents. More significantly, it is also lacking from the Hikayat Bayan Budiman's two earliest surviving manuscripts, both datable to $c a .1500$. Although one of these is incomplete, containing only two and half stories, the other, comprising ten stories, is intact. Both include only Persian-derived tales; the eight Malay tales emerge from the eighteenth century onwards. Arguably, therefore, they (and their use of lebai) reflect a later period.

Although early Islamic epigraphy from the Peninsula is exceptionally rare, one notable example survives at Kampung Pengkalan Kempas, a village situated in modern-day Negeri Sembilan (Malaysia). ${ }^{13}$ On the outskirts of this settlement stands a fifteenth-century Melakan mortuary structure known locally as Kramat Sungai Udang. Comprising a large 
tiered stone platform surrounded by several (possibly pre-Islamic) megaliths, at its foot is a rectangular stone stele inscribed on all four sides in Malay. Beginning on the northern and ending on the southern side runs a continuous kawi (Old Javanese script) inscription identifying the grave's occupant as a Muslim called Ahmat Majanu. Aside from the basmillah and greeting saläm, this inscription utilizes no Islam-specific vocabulary, in any language (Casparis 1980, 18-21). The two remaining sides of the stele, on the other hand, carry separate Jawi inscriptions that, although formulaic and near-identical, employ a plethora of Arabic terminology. These include stand-alone phrases (like the basmillah) and fully incorporated loanwords (such as zaman, used to denote "era"). Concerning Ahmat Majanu's designation, both Jawi inscriptions accord him the Arabic title shaykh; neither utilizes lebai (Kloss 1921, 185-89). Both inscriptions therefore reinforce the impression Melakan Islamic terminology was drawn predominantly from Arabic.

By contrast, for the earliest attestation to lebai on the Malay Peninsula, we must turn to the Hikayat Hang Tuah, a Johor text written between 1641 and 1710 (Braginsky 1990, 403). An elaborate, semimythic biography of the famed Melakan warrior Hang Tuah, this text utilizes lebai seven times, applying it on each occasion to a religious teacher under whom Hang Tuah supposedly learnt a specific language. Thus, he is described as learning Siamese under a lebai Siam, Chinese under a lebai Cina, Javanese under a lebai Jawa and, finally, Tamil under a lebai Keling. All these individuals were supposedly residents of Bentan, an island near Singapore (K. Ahmad 1966, 21, 375). Between the mid- to late seventeenth century, therefore, lebai had entered the Malay Peninsula.

In the absence of additional textual material, a more definitive reconstruction of lebais passage through Southeast Asia is difficult. Nonetheless, the surviving evidence indicates that lebai first emerged on Java prior to 1512-1515. By 1600, it had travelled westward to north Sumatra, before finally penetrating the Malay Peninsula later that same century-or roughly contemporary to leppais first appearance in Tamil. It is the term's initial association with Java, however, that draws our attention; recent efforts to sketch a significant Sino-Muslim role within Java's Islamization prove potentially indicative of an alternative, Chinese etymon. 


\section{A Possible Sino-Muslim Origin}

Several scholars have sought to justify an important Sino-Muslim role in Java's initial Islamization (Pigeaud and De Graaf 1976; Ptak 2001; Wade 2012; A. Wain 2017). While emphasizing the numerous references to Sino-Muslims within early Javanese texts (below), they have attempted to (at least partially) re-orientate the maritime trade of thirteenth- to fifteenth-century Southeast Asia towards China (see Lombard and Salmon, 1985). Traditionally, early Southeast Asian commerce has been interpreted as the conduit by which Islam entered the region; by portraying that commerce as Indian Ocean dominated, scholars have been able to justify Arab and/or Indian involvement in Islamization (Drewes, 1968). Recent archaeological discoveries, however, have problematized this reconstruction: substantial deposits of Chinese trade goods (notably ceramics), evidence of regional Chinese trading outposts, and indications of cultural and technological exchange (notably in the areas of ceramic production and shipbuilding) suggest Southeast Asia interacted with China just as intensely as with the Indian Ocean over this period (Ho 1995; Manguin 2010; McKinnon 1977; Miksic and Yian 2017; A. Wain 2020).

Indeed, early Chinese records confirm both the reality and intensity of these interactions; by the twelfth century, or consonant with the Song period (960-1279), they are also explicit about the importance of Sino-Muslims within the resultant trade networks (Heng, 2009). ${ }^{14}$ Over the early thirteenth century, for example, Zhao Rugua (d. 1228), Superintendent of Maritime Trade for Fujian province, would describe southern China’s Muslim merchants as the region's wealthiest (Zhao 1966, 116-19). ${ }^{15}$ Nevertheless, Muslim involvement in Chinese maritime trade would only reach its zenith, when the Mongol Yuan dynasty (1279-1368) placed their Muslim administrators in charge of government-instituted Mercantile Shipping and Transportation Bureaux. First established in 1284, these Bureaux were responsible for issuing trading licences to ship captains $;{ }^{16}$ the Yuan forbade the issuance of such licences to anyone other than a Muslim in order to reduce the power and wealth of the Han, whom they distrusted (Heng 2009, 65-66). In consequence, the early Yuan saw China's Muslims extend their commercial dominance across all aspects of China's maritime trade. While this supremacy proved short-lived, its aftermath prompted extensive Sino-Muslim migration to Southeast Asia, particularly to Java. 
According to the Yuanshi (元史, Imperial Records of the Yuan Dynasty), in 1357, as Yuan authority began to crumble, two Sino-Muslim generals of Persian descent, Amir al-Din (A-mi-li-ding) and Sayf al-Din (Sai-fuding), faced with increasing Han commercial competition and declining Imperial authority, rebelled. Taking control of the pre-eminent Fujianese port city of Quanzhou, they initiated the Hongjin Qiyi (紅巾起義, Red Turban Rebellion). This movement rapidly spread throughout Fujian until, by 1362, it was within reach of the provincial capital, Fuzhou. At that point, however, Imperial troops forced the rebels back, eventually defeating them completely in 1366. Subsequently, another Yuan general, Chen Youding, assisted by an apparently Persian Shia called Jin Ji, began the methodical extermination of all Quanzhou's Sunni Muslims, ostensibly to prevent further rebellious activity. This persecution became widespread, resulting in a Sino-Muslim exodus to Southeast Asia (Wade 2010, 386-87). Although these migrants ultimately became dispersed throughout the region, a large concentration settled on Java; the Yingyai shenglan (瀛涯胜览, Overall Survey of the Ocean's Shores) of Ma Huan (ca.1380-1460), an eye-witness account of the seven famous voyages of Zheng He (conducted 1402-1433), states the following concerning them:

They are all men from Guangdong and from Zhangzhou and Quanzhou [in Fujian] and other such places, who fled away and now live in this country...many of them follow the Muslim religion, doing penance and fasting. ${ }^{17}$ (Ma-Huan 1970, 93)

During the mid-fourteenth century, therefore, or more than one hundred and fifty years prior to lebais first appearance on Java, that island became host to a significant Sino-Muslim population rooted in the Guangdong and Fujian regions of southern China. On the basis of indigenous Javanese texts (below), many scholars have argued that this population subsequently proved pivotal in the Islamization of Java, a process which began shortly after their arrival (Pigeaud and De Graaf 1976; Wade 2010; A. Wain 2017). Within this context, it is pertinent to note that Sino-Muslims, although lacking a distinct language of their own, possess a specialized Islamic vocabulary known as "Hui Speech" (huihui hua, 回回話). Initially developed over the Song period, this speech permeated Sino-Muslim use of China's various languages and dialects, acting as a linguistic marker of ethnic and religious identity. As outlined by D. Gladney, while being suffused with Arabic, Persian 
and Turkish terminology, this vocabulary also incorporated numerous Chinese words appropriated from Chinese folk, Buddhist and Daoist traditions. Amongst these is the noun libai (禮拜), used to denote "worship" or a "religious service" conducted in a mosque (Gladney 1996, 393, 406).

Although libai has a long pre-Islamic history, its use amongst SinoMuslims evolved out of early attempts to develop an adequate Chineselanguage designation for the mosque. Initially, during the Tang dynasty (618-907), Sino-Muslims styled their mosques litang (禮堂, lit. "halls of ceremony"). Over the Song, however, in an effort to craft a more precise meaning, this term was augmented with the Chinese character for “worship” (拜, bai), creating libaitang (禮拜堂, “halls of worship”), which finally became libaisi (禮拜寺, “temples of worship”) during the Yuan (Dillon 2013, 93). Sino-Muslim use of libai therefore originated under the Song, specifically as a term for worship conducted in a mosque, before subsequently spreading across southern China's Muslim communities, notably in Guangdong and Fujian (where it retains the same pronunciation). This association with Sino-Muslim acts of worship has since predominated, to the point that non-Muslim Han no longer utilize libai as a designate for "worship." 18 In contrast to lebai, however, libai does not refer to individuals concerned with conducting acts of worship in a mosque, but to the acts of worship themselves. ${ }^{19}$ These meanings are, however, clearly related: they bear upon the same body of religious praxis conducted in association with the same religious institution. Given the phonetic similarity between them, could libai (as the earlier term) therefore constitute the origin of lebai?

Certainly, Malay harbors numerous Chinese loanwords. Although the absence of a definitive study renders the precise scale of this borrowing uncertain, the most comprehensive study so far undertaken has identified somewhere in the order of 1,086 words (Jong-Min, 2007). ${ }^{20}$ As initially noted by A. W. Hamilton $(1924,48,51,54)$, the majority relate to Chinese cuisine (including articles of food and household utensils), games of chance and religious manifestations. Although scholars agree the bulk of these terms entered Malay over the nineteenth to early twentieth centuries, or contemporary to substantial colonial-era Chinese migration to Southeast Asia, evidence also exists for earlier borrowings (Jones 2009; Maria 1974, 371). The aforementioned 
fifteenth-century Malay-Chinese vocabulary produced in Melaka, for example, lists five Chinese loanwords in Malay, including cawan (“cup,” from cha 茶, “tea," and wan 碗, “cup”) (Edwards and Blagden 1931, 734-35). Pigafetta's vocabulary, meanwhile, adds sampan ("boat," from san 三, “three," and ban 板, “plank”) (Bausani 1960, 238). These borrowings establish Chinese-Malay linguistic interaction contemporary to the appearance of lebai on Java. Moreover, scholars agree that these early Chinese loanwords (in addition to many later ones) originated with the Hokkien (South Fujian) dialect (Jones 2009). As mentioned, Sino-Muslim use of libai can be found across southern China, including in Fujian.

The context in which lebai first emerged on Java also suggests a possible link with libai. It will be recalled that Pires identifies Cirebon's first Muslim ruler as a slave from Gresik. Ma Huan states the following concerning Gresik:

Originally it was a region of sandbanks; [and] because people from the Central Country [China] came to this place and established themselves, they therefore called it New Village [Xin Cun]; right down to the present day the ruler of the village is a man from Guangdong. There are something more than a thousand [Chinese] families [here]. (Ma-Huan 1970, 89-90)

According to Ma Huan, therefore, Gresik was a Chinese-founded settlement, ruled by Chinese immigrants from Southern China-the same immigrants he earlier described as predominantly (and actively) Muslim. Moreover, although Pires does not specifically identify the aforementioned slave from Gresik as Sino-Muslim, he does link that individual to the first "lord of Demak," identified in many indigenous texts as a Sino-Muslim merchant from Gresik, called either $\mathrm{Cu} \mathrm{Cu}$ or Jinbun. ${ }^{21}$ In consequence, the available evidence suggests Lebe Uça, first-known holder of the Malay title lebai, governed a city whose Muslim past began less than half a century earlier in association with Demak's powerful Sino-Muslim ruler and a slave from Chinese-founded Gresik. Arguably, therefore, and given the well-known Chinese cultural influences associated with Cirebon, ${ }^{22}$ Lebe Uça resided within an environment suffused with Sino-Muslim influence; plausibly huihui hua, already in use for several centuries, circulated within that environment, where utilization of libai, denoting everyday acts of worship, might be realistically expected. In light of the problems associated with a possible Tamil derivation for lebai, in addition to the lack of an obvious etymon 
from within Arabic, Persian, Turkish or Urdu, we propose that lebais phonetic and semantic similarity to libai establishes the latter as its etymon. Within this context, however, it might be asked how the noun libai (Muslim act of worship) morphed into lebai (a religious scholar who leads such acts of worship). Unfortunately, no textual evidence survives to illuminate this point, or indeed confirm whether lebai also once designated "worship". This sparsity of evidence is a consequence of the fragmentary nature of the available textual material. Certainly, similar examples of semantic drift are known to have occurred over this period in association with Arabic loanwords in Malay, yet without any surviving evidence to suggest how such drift took place. The Malay petua, for example, is a noun signifying "advice" or "lesson" (usually from older people possessing religious knowledge) and derives from the Arabic fatwá, bearing the far more specialized meaning of a formal legal opinion issued by a mufti (Wilkinson 1901, 454). Likewise, the Malay noun keparat derives from the Arabic kafarah (penance), yet is more commonly utilized as a term of abuse (swear word) (Wilkinson 1901, 521). The mechanism underlying these alterations is unattested, yet verifiably took place. Speculatively, libai may also have undergone a process of change whereby the person concerned with mosque religious services came to be designated by the term originally used to denote that act of worship itself.

\section{Conclusion}

This article has sought to establish a new etymon for the Malay word lebai, one capable of recasting it as the product of Sino-Muslim activity on early Islamic Java. Beginning with a brief outline of the currently accepted etymology, which roots lebai in the Tamil leppai, our article argued this relationship be reversed. Evidence establishing lebai's presence amongst Malay-speakers more than 130 years before leppai appears in Tamil, coupled with pre-modern Southeast Asia's evident ability-contrary to some prior assumptions-to project its unique Islamic culture into the Indian Ocean, establishes leppai as a probable derivation of lebai, not vice versa. Building upon this conclusion, a careful consideration of lebai's earliest attestations reveals early sixteenth-century Cirebon (Java) as a probable point of origin, where it was used as a title for the city's Muslim ruler, Lebe Uça. According to early Portuguese sources, Cirebon became Islamic under 
the aegis of the first Muslim "lord of Demak," who installed a slave from Gresik as that city's first Muslim ruler. Significantly, later Javanese sources consistently attribute Chinese ancestry to this "lord of Demak," naming him either $\mathrm{Cu} \mathrm{Cu}$ or Jinbun, while Chinese sources speak of substantial Sino-Muslim migration to Java over the fourteenth century, with at least one text (Ma Huan's Yingyai Shenglan) identifying Gresik as a Chinese-founded city. Within that context, an alternative etymon for lebai emerges: the Sino-Muslim libai (禮拜), used from the Song period onwards to designate worship or religious services conducted in a mosque. Although this referent differs from the precise meaning of lebai, the two words have similar connotations and pronunciations. In the context of the evidence reviewed here, libai may therefore constitute the source of the Malay term, having presumably been introduced into Southeast Asia by fourteenth-century Sino-Muslim immigrants to Java. This possibility adds further nuance to our understanding of Southeast Asia’s Islamization. 


\section{Endnotes}

1. Throughout this article, "Sino-Muslim" denotes a pre-modern Muslim resident of China. Generally of Persian, Central Asian or Arab descent, they arrived in China as early as the seventh century, originally as traders. By the late thirteenth century, when this discussion begins, many were permanent settlers, constituting members of long-standing diaspora communities. As outlined by J. Chaffee, diasporas constitute communities that, while socially related to their host communities, nonetheless remain "an alien element in the wider society in which they become settled" (Chaffee 2006, 396). Despite the prefix "Sino-", these Muslims cannot therefore be considered Chinese in the same sense as the Han. Although they acculturated to a degree, they also actively maintained traditions rooted in their homelands, resulting in the emergence of a distinctly Chinese form of Islam by at least the fourteenth century, one characterized by use of the Chinese language and an admixture of Islamic and Chinese customs (K. R. Hall 2006, 455-56).

2. It is not found amongst instances of pre-Islamic Malay epigraphy (T. G. Hoogervorst 2015b, 250-53). It also fails to appear in texts central to Southeast Asia's pre-Islamic tradition, including the Hikayat Seri Rama (a Malay version of the Ramayana) and various works dealing with the heroes of the Mahabharata, of which the Hikayat Pandawa Lima is the most detailed and complete. Although these texts are rooted in the pre-Islamic period, generally they survive as later editions, shaped by successive waves of Islamic influence (Hussain 1992a; Zieseniss 1963).

3. Prior to Van Ronkel, scholarship made no connection between lebai and leppai. R. J. Wilkinson's comprehensive Malay-English dictionary, for example, first published 1901, identifies numerous Tamil loanwords in Malay, but does not include lebai (defined as a "mosque official") amongst them (Wilkinson 1901, 596). A. W. Hamilton's list of Indian loanwords in Malay, designed to fill any lacunas left by Wilkinson, does not list lebai either (Hamilton 1919, 29-38).

4. According to Drewes, Arnold's equating of leppai with 'arabi reflects a popular misconception amongst early twentieth-century Tamils concerning the origin of this term (G.W.J. Drewes 1968, 458).

5. G. E. Marrison foregrounds the Hikayat Raja Pasais account of Samudera-Pasai's conversion, which links that event to an Indian location called Ma'abri (or possibly Mengiri). Marrison associates the name of this kingdom with the Arabic ma'bar (crossing point), an appellation pre-modern Arab traders applied to the Madurai and Tanjore districts of South India - the former of which even hosted a Sultanate of Ma'bar from 1335 to 1378 (Marrison 1951, 31). K. R. Hall further points to objects of South Indian origin amongst Samudera-Pasai's coronation regalia, including a distinctive ankle bracelet supposedly gifted to the kingdom's first sultan (K. R. Hall 1977, 221). More recently, R. Ricci has postulated the existence of a post-sixteenth-century, Tamil-enabled Muslim literary network extending right across Southeast Asia (Ricci 2009, 2010).

6. For example, a Tamil merchant called Sidi Lebbe controlled Perak's tin trade over the late 1680 s, with a prosperous Tamil "labbai family" operating out of Johor during the same period (Arasaratnam 1986, 126, 147).

7. Early Portuguese accounts confirm nayna's association with both Muslim and nonMuslim Tamil merchants (Thomaz, 1991).

8. The application of leppai to an endogamous group from northern Tamil Nadu represents a probable European innovation; the British, observing that Urdu-speaking residents in or near northern Tamil Nadu commonly referred to Tamil merchants as leppai, adopted that term as an ethnic label. Subsequently, the Tamil community in question followed suit, self-identifying as leppai (Tschacher 2009, 52). 
9. When tracing the various attestations to lebai discussed in this section, I have utilized the excellent Malay Concordance Project, hosted by the Australian National University and formerly maintained by the late Ian Proudfoot, see: http://mcp.anu.edu.au/.

10. For the earliest known Javanese language Muslim texts, both seventeenth century, see Drewes $(1969,1978)$.

11. Although present within this vocabulary, lebai remains absent from other Acehnese texts produced over this period, including a ca.1604 Malay translation of the Arabic text Qasidah al-Burdah (written in the 1200s) (G.W.J. Drewes 1955), the Taj al-Salatin of Bukhari al-Jauhari (written 1602) (Eysinga 1827; Hussain 1992b), and an anonymous collection of Sufi tracks from Samudera-Pasai (undated, but unquestionably pre-1650) (Johns 1957).

12. Initial studies considered Pigafetta's vocabulary to be a product of his brief 1521 stay in the Moluccas (Gonda 1938). A. Bausani and others, however, have rejected this hypothesis, noting that the text contains no Moluccan-Malay words. Since Pigafetta was not conversant in Malay, the source for his vocabulary is uncertain. Between September 20, 1519, and April 27, 1521, however, he sailed alongside Henrique (or Enrique) the Melakan, the Malay-speaking slave of Magellan. According to Magellan's Last Will, Henrique was a native of Melaka captured during the 1511 Portuguese siege of that city. He therefore constitutes a plausible source for this vocabulary (Bausani 1960, 230-32). That Pigafetta traces Henrique's origins to Sumatra is of little concern; classical Malay was also commonly used there (Andaya 2016, 49; Pigafetta 2007, 34).

13. For a full account of the site, including its early twenty-century excavation, see (Evans 1921). Also surviving from the Melaka period are the memorials of sultans Mansur Shah and 'Ala ud-din Shah (r.1477-1488), and the gravestones of two residents of the city, Nakhoda Haji Kanbaiy (d.1459) and Ismail Haji Nasaruddin (d.1480). All are inscribed in Arabic and none bear lebai (Yatim and Nasir 2007, 61-64).

14. In 1134, for example, tax officials operating in the important Fujianese port of Quanzhou informed the Imperial Court that a Sino-Muslim engaged in overseas trade had recently amassed a taxable revenue of 300,000 strings of cash on a cargo of frankincense. This was a sizable amount; Quanzhou's annual tax revenues over this period averaged only 1,000,000 strings per year (Clark 1991, 132-34).

15. In particular, official records from this period draw attention to the powerful Muslim $\mathrm{Bu}$ (or $\mathrm{Pu}$ ) clan. Of apparent Arab ancestry, by the thirteenth century this clan constituted southern China's wealthiest merchant association. From 1250 to 1280, its leader, Bu Shougeng, acted as Superintendent of Quanzhou. In this role, he controlled all the city's trade, including to Southeast Asia. Under the subsequent Yuan dynasty, Bu Shougeng reached still greater heights, becoming Grand Commander of Fujian, with full control over all Fujianese provincial trade, a role later maintained by his descendants (Wade 2010, 380-81, 387, 415).

16. These Bureaux also had responsibility for providing oceangoing ships (now built solely in government shipyards) and the personnel to man them (Leslie, 1986: 98).

17. In this and the following quotation, I have standardized Mills' transliteration to pinyin.

18. Later, China's Christians also adopted libai as a designation for church services. From the early nineteenth century, the wider Chinese population has utilized libai as a colloquialism for "week". This usage stems from the observation that Muslims and Christians only attend their places of worship once a week (Ross and Jing-heng 2006, 318).

19. Over the relevant period, a Sino-Muslim individual concerned with religious affairs in a mosque bore the Persian-derived title ahong (阿言) (Gladney 1996, 395).

20. There are also a number of Malay loanwords in Chinese (Salmon 2009).

21. According to the Hikayat Hasanuddin, the first ruler of Demak was a Sino-Muslim 
immigrant called $\mathrm{Cu} \mathrm{Cu}$ who began his career as a Gresik-based merchant (Edel 1938, 122). The heavily mythologized court chronicle of Mataram, the Babad Tanah Jawi (composed 1690-1718), likewise attributes Chinese ancestry to this individual; naming him Jinbun, it traces his parentage to Majapahit's final ruler and an unnamed Chinese princess (Olthof 2012, 29-30). While J. Ras has convincingly dismissed this reference to Majapahit ancestry as an attempt to legitimize Mataram's ruling house, which claimed descent from Majapahit's semi-divine rulers via Demak (Ras 1987, 353-54), the parallel mention of a Chinese princess could represent an acknowledgement of earlier Javanese traditions linking Demak's ruling house to China. Certainly, Pires also references the Chinese ancestry of several early Javanese Muslim lords, although without specifying which ones (Pires 2005, 182). The Purwaka Caruban Nagari is also potentially relevant here. Reputedly the eighteenth-century court chronicle of Cirebon, this text likewise identifies Demak's first Muslim ruler as a man named Jinbun, the supposed son of Majapahit's final ruler and a Chinese girl. Here, the latter is identified as a Sino-Muslim girl from Gresik named Siu Ban Ci, supposedly the daughter of a merchant and religious scholar named Tan Go Hwat (or Kyai Bantong) (Atja 1986). The authenticity of the Purwaka Caruban Nagari is, however, doubtful. In 1987, M. C. Ricklefs examined the only known manuscript copy; observing the use of modern writing materials (lined notebook paper), anomalies in both palaeography and contents (notably the use of Western not Javanese dating methods), and its discovery alongside other texts known to be questionable, Ricklefs concluded it was probably a twentieth-century forgery (Ricklefs 2008, 416).

22. Most notably, Chinese influences are apparent throughout Cirebon's early Islamic architecture, much of it datable to the period under discussion (A. Wain 2015, 392404). Although later, Chinese artistic influences are also found in association with Cirebon's palace architecture and batik (decorated textile) tradition (Kerlogue 2004, 134, $138,164)$.

\section{Bibliography}

Ahmad, A. Samad. 1987. Hikayat Amir Hamzah. Kuala Lumpur: Dewan Bahasa dan Pustaka, Kementerian Pelajaran Malaysia.

Ahmad, Kasim. 1966. Hikayat Hang Tuah. Kuala Lumpur: Dewan Bahasa dan Pustaka.

Al-Attas, Syed Muhammad Naguib. 1970. The Mysticism of Hamzah Fansuri. Kuala Lumpur: University of Malaya Press.

Andaya, Leonard Y. 2016. Leaves of the Same Tree: Trade and Ethnicity in the Straits of Melaka. Singapore: NUS Press.

Arasaratnam, Sinnappah. 1986. Merchants, Companies, and Commerce on the Coromandel Coast, 1650-1740. Delhi: Oxford University Press.

Armstrong, James. 2020. "A Footnote on Shaykh Yusuf." Quarterly Bulletin of the National Library of South Africa 74(1): 9-14. 
Arnold, T. W. 1927. "Labbai.” In Encyclopaedia of Islam, eds. M. Th Houtsma, R. Hartmann, and R. Basset. Leiden and London: E. J. Brill and Luzac and Co.

Atja. 1986. Carita purwaka Caruban nagari: karya sastra sebagai sumber pengetahuan sejarah. Cirebon: Pusat Pengembangan Permuseuman Jawa Barat.

Azra, Azyumardi. 2004. The Origins of Islamic Reformism in Southeast Asia: Networks of Malay-Indonesian and Middle Eastern "Ulama" in the Seventeenth and Eighteenth Centuries. Crows Nest: Allen \& Unwin.

Bausani, Alessandro. 1960. "The First Italian-Malay Vocabulary by Antonio Pigafetta." East and West 11(4): 229-48.

Bayly, Susan. 1989. "Islam and State Power in Pre-Colonial South India." In India and Indonesia during the Ancien Regime, ed. P. J. Marshall, Robert Van Niel et al. Leiden: E. J. Brill, 143-64.

Boxer, C. R. 1969. "A Note on Portuguese Reactions to the Revival of the Red Sea Spice Trade and the Rise of Atjeh, 1540-1600." Journal of Southeast Asian History 10(3): 415-28.

Braginsky, V. I. 1990. "Hikayat Hang Tuah; Malay Epic and Muslim Mirror; Some Considerations on Its Date, Meaning and Structure." Bijdragen tot de taal-, land-en volkenkunde / Journal of the Humanities and Social Sciences of Southeast Asia 146(4): 399-412.

- 2004. The Heritage of Traditional Malay Literature: A Historical Survey of Genres, Writings and Literary Views. KITLV Press. https://brill.com/view/ title/23610 (August 12, 2021).

Brakel, L. F. 1977. The Story of Muhammad Hanafiyyah: A Medieval Muslim Romance. The Hague: Martinus Nijhoff.

Casparis, Johannes Gijsbertus. 1980. “Ahmat Majanu’s Tombstone at Pengkalan Kempas and Its Kawi Inscription." Journal of the Malaysian Branch of the Royal Asiatic Society 53(1): 1-22.

Chaffee, John. 2006. "Diasporic Identities in the Historical Development of the Maritime Muslim Communities of Song-Yuan China." Journal of the Economic and Social History of the Orient 49(4): 395-420.

Cheah, Kheng Boon. 2010. Sejarah Melayu: MS Raffles No. 18 Edisi Rumi Baru, Transcr. Abdul Rahman Haji Ismail. Kuala Lumpur: The Malaysian Branch of the Royal Asiatic Society.

Clark, Hugh R. 1991. Community, Trade, and Networks: Southern Fujian Province from the Third to the Thirteenth Century. Cambridge: Cambridge University Press.

Dillon, Michael. 2013. China's Muslim Hui Community: Migration, Settlement and Sects. London: Routledge. 
Drewes, G.W.J. 1955. Een 16th Eeuwse Maleise Vertaling van de Burda van AlBusiri (Arabische Lofdicht Op Mohammad). 's-Gravenhage: Nijhoff.

1968. "New Light on the Coming of Islam to Indonesia?" Bijdragen tot de Taal-, Land-en Volkenkunde / Journal of the Humanities and Social Sciences of Southeast Asia 124(4): 433-59.

-1969. Kitab Bonang: The Admonitions of Seh Bari; 16th Century Javanese Muslim Text Attributed to the Saint of Bonan. The Hague: M. Nijhoff, The Hague.

1978. An Early Javanese Code of Muslim Ethics. The Hague: M. Nijhoff.

Edel, J. 1938. Hikayat Hasanuddin. Meppel: Ten Brink.

Edwards, E. D., and C. O. Blagden. 1931. "A Chinese Vocabulary of Malacca Malay Words and Pharases Collected Between A.d. 1403 and 1511.” Bulletin of the School of Oriental and African Studies 6(3): 715-49.

Evans, Ivor H. N. 1921. "A Grave and Megaliths in Negri Sembilan with an Account of Some Excavations." Journal of the Federated Malay States Museums $9(3): 155-73$.

Eysinga, P. P. Roorda van. 1827. De Kroon Aller Koningen, van Bocharie van Djohor, Naar Cen Oud Malaische Geschrift Vertaald. Batavia: Lands Drukkerij.

Fang, Liaw Yock. 1976. Undang-Undang Melaka (the Laws of Melaka). The Hague: Martinus Nijhoff.

Feener, R. Michael. 2009. "Issues and Ideologies in the Study of Regional Muslim Cultures." In Islamic Connections: Muslim Societies of South and Southeast Asia, ed. Terenjit Sevea. Singapore: Institute of Southeast Asian Studies Press, 1323.

Gladney, Dru C. 1996. Muslim Chinese: Ethnic Nationalism in the People's Republic. Cambridge, MA: Harvard Univ Asia Center.

Gonda, J. 1938. "Pigafetta's Vocabularium van Het, Molukken-Maleisch." Bijdragen tot de taal-, land-en volkenkundelJournal of the Humanities and Social Sciences of Southeast Asia 97(1): 101-24.

Guillot, Claude. 2004. "La Perse et le Monde malais. Échanges commerciaux et intellectuels." Archipel 68(1): 159-92.

Hall, Kenneth R. 1977. "The Coming of Islam to the Archipelago: A Reassessment." In Economic Exchange and Social Interaction in Southeast Asia: Perspectives from Prehistory, History, and Ethnography, ed. Karl L. Hutterer. Ann Arbor: University of Michigan Press, 213-32.

2006. "Multi-Dimensional Networking: Fifteenth-Century Indian Ocean Maritime Diaspora in Southeast Asian Perspective." Journal of the Economic and Social History of the Orient 49(4): 454-81. 
Hamilton, A. W. 1919. "Hindustani, Tamil, Sanskrit and Other Loan Words in Malay." Journal of the Straits Branch of the Royal Asiatic Society (80): 29-38.

_. 1924. "Chinese Loan-Words in Malay." Journal of the Malayan Branch of the Royal Asiatic Society 2(1 (90): 48-56.

Heng, Derek. 2009. Sino-Malay Trade and Diplomacy from the Tenth through the Fourteenth Century. Athens, OH: Ohio University Press.

Hj Musa, Hashim. 2003. Sejarah Sistem Tulisan dalam Bahasa Melayu. Kuala Lumpur: Dewan Bahasa dan Pustaka.

Ho, Chuimei. 1995. "Intercultural Influence between China and South East Asia as Seen in Historical Ceramics." In South East Asia and China: Art, Interaction and Commerce, ed. R. Scott and J. Guy. London: Percival David Foundation of Chinese Art and The School of Oriental and African Studies, 118-40.

Hoogervorst, Tom G. 2015a. "Detecting Pre-Modern Lexical Influence from South India in Maritime Southeast Asia.” Archipel. Etudes interdisciplinaires sur le monde insulindien (89): 63-93.

- 2015b. "Tracing the Linguistic Crossroads between Malay and Tamil." Wacana 16(2): 249-83.

Hurgronje, Christiaan Snouck. 1916. Mohammedanism: Lectures on Its Origin, Its Religious and Political Growth and Its Present State. New York: GP Putnam's Sons.

Hussain, Khalid M. 1986. Hikayat Iskandar Zulkarnain. 2nd ed. Kuala Lumpur: Dewan Bahasa dan Pustaka.

—. 1992a. Hikayat Pandawa Lima. Kuala Lumpur: Dewan Bahasa dan Pustaka.

1992b. Taj al-Salatin. Kuala Lumpur: Dewan Bahasa dan Pustaka.

Iskandar, Teuku. 1995. Kesusasteraan Klasik Melayu Sepanjang Abad. Jakarta: Libra.

Johns, Anthony Hearle. 1957. "Malay Sufism: As Illustrated in an Anonymous Collection of 17th Century Tracts." Journal of the Malayan Branch of the Royal Asiatic Society 30(2): 1-110.

Jones, Russell. 1999. Hikayat Raja Pasai. Kuala Lumpur: Yayasan Karyawan and Fajar Bakti.

- 2007. Loan-Words in Indonesian and Malay. Leiden: KITLV Press.

- 2009. "The Chiangchew Hokkiens, the True Pioneers in the Nanyang." Journal of the Malaysian Branch of the Royal Asiatic Society 82(2): 39-66.

Jong-Min Won. 2007. "A Study on the Learning of Chinese Loan Words in Malay-Indonesian Language." Studies in Foreign Language Education 21(1): 
$77-120$.

Kerlogue, Fiona. 2004. Arts of Southeast Asia. London: Thames \& Hudson.

Kloss, C. Boden. 1921. "Notes on the Pengkalan Kempas Tombstone." Journal of the Federated Malay States Museums 9(3): 185-89.

Lambourn, Elizabeth. 2004. "The Formation of the Batu Aceh Tradition in Fifteenth-Century Samudera-Pasai." Indonesia and the Malay World 32(93): $211-48$.

2008. "Tombstones, Texts, and Typologies: Seeing Sources for the Early History of Islam in Southeast Asia." Journal of the Economic and Social History of the Orient 51(2): 252-86.

Lombard, Denys. 1970. "Ende Woord-Boek" De Frederick de Houtman: Première Méthode De Malais Parlé (Fin Du Xvi S.). Paris: École française d'ExtrêmeOrient.

Ma-Huan. 1970. Ying-Yai Sheng-Lan: "The Overall Survey of the Ocean's Shores" (1433). ed. Chengjun Feng. Cambridge: CUP Archive.

Majul, Cesar Adib. 1999. Muslims in the Philippines. Philippines: University of the Philippines Press.

Manguin, Pierre-Yves. 2010. "New Ships for New Networks: Trends in Shipbuilding in the South China Sea in the 15th and 16th Centuries." In Southeast Asia in the Fifteenth Century: The China Factor, eds. Geoff Wade and Sun Laichen. Singapore: NUS Press, 333-58. https://halshs.archives-ouvertes. fr/halshs-02521876 (August 13, 2021).

Mansoer, M. D. 1963. "Masuk Dan Berkembangnja Agama Islam Di Daerah Pesisir Utara Sumatra." In Risalah Seminar Sedjarah Masuknja Islam Ke Indonesia: Kumpulan Pedato, Restu Dan Pendapat Para Pemimpin Pemerasaran Dan Pembanding Dalam Seminar Tgl. 17 Sampai 20 Marat 1963 Di Medan, $55-71$.

Maria, Luigi Santa. 1974. "Linguistic Relations between China and the MalayIndonesian World." East and West 24(3/4): 365-80.

Marrison, G. E. 1951. "The Coming of Islam to the East Indies." Journal of the Malayan Branch of the Royal Asiatic Society 24(1): 28-37.

McKinnon, E. E. 1977. "Research at Kota Cina, a Sung-Yüan period trading site in East Sumatra." Archipel 14(1): 19-32.

Miksic, John Norman, and Goh Geok Yian. 2017. Ancient Southeast Asia. London: Routledge.

Montana, Suwedi. 1997. "Nouvelles données sur les royaumes de Lamuri et Barat." Archipel 53(1): 85-95.

More, J. B. Prashant. 2004. Muslim Identity, Print Culture, and the Dravidian 
Factor in Tamil Nadu. Hyderabad: Orient Blackswan.

Olthof, W. L. 2012. Babad Tanah Jawi, mulai dari Nabi Adam sampai tahun 1647. Yogyakarta: Narasi.

Perret, Daniel, Heddy Surachman, and Ludvik Kalus. 2017. "Enam Abad Seni Makam Islam Di Barus." In Makam-Makam Islam Lama Di Maritim Asia Tenggara, eds. Daniel Perret, Arbai'yah binti Mohd Noor, Jamil bin Haron, and Mahat Afifi bin Mohamed Salleh. Kuala Lumpur: Jabatan Muzium Malaysia and École français d'Extrême-Orient, 297-351.

Pigafetta, Antonio. 2007. The First Voyage Around the World, 1519-1522: An Account of Magellan's Expedition. Toronto: University of Toronto Press.

Pigeaud, Theodore Gauthier Th, and H.J. De Graaf. 1976. Islamic States in Java 1500-1700 : A Summary. The Hague: Martinus Nijhoff.

Pires, Tomé. 2005. The Suma Oriental of Tomé Pires: An Account of the East, from the Red Sea to China, Written in Malacca and India in 1512-1515. New Delhi: Asian Educational Services.

Ptak, Roderich. 2001. "Quanzhou: At the Northern Edge of a Southeast Asian 'Mediterranean."' In The Emporium of the World: Maritime Quanzhou, 10001400, ed. Angela Schottenhammer. Leiden: E. J. Brill, 395-427.

Ras, Johannes Jacobus. 1987. "The Genesis of the Babad Tanah Jawi: Origin and Function of the Javanese Court Chronicle." Bijdragen tot de Taal-, Land-en Volkenkunde / Journal of the Humanities and Social Sciences of Southeast Asia 143(2/3de Af): 343-56.

Ricci, Ronit. 2009. "Conversion to Islam on Java and the Book of One Thousand Questions." Bijdragen tot de taal-, land- en volkenkunde / Journal of the Humanities and Social Sciences of Southeast Asia 165(1): 8-31.

- 2010. "Islamic Literary Networks in South and Southeast Asia." Journal of Islamic Studies 21(1): 1-28.

- 2011. Islam Translated: Literature, Conversion, and the Arabic Cosmopolis of South and Southeast Asia. Chicago: University of Chicago Press.

Ricklefs, M. C. 2008. A History of Modern Indonesia Since C.1200. Hampshire: Macmillan International Higher Education.

Rinkes, D. A. 1996. Nine Saints of Java. ed. Alijah Gordon. Kuala Lumpur: Malaysian Sociological Research Institute. https://dspace.library.uvic.ca/ handle/1828/8115 (August 14, 2021).

Ronkel, Zie Ph S. van. 1914. "Maleisch Labai, Een Moslimsch-Indische Term." Tijdschrift Bataviaasch Genootschap 56: 137-42.

Ross, Claudia, and Sheng Ma Jing-heng. 2006. Modern Mandarin Chinese Grammar: A Practical Guide. London: Routledge. 
Salmon, Claudine. 2009. "Malay (and Javanese) Loan-Words in Chinese as a Mirror of Cultural Exchanges." Archipel 78(1): 181-208.

Singh, K. S. 1998. India's Communities: Anthropological Survey of India. Delhi: Oxford University Press.

Subbarayalu, Y. 1998. "The Tamil Merchant-Guild Inscription at Barus. A Rediscovery." In Volume 1: Etudes et Documents, Vol. 1 of Histoire de Barus, Sumatra: Le Site de Lobu Tua, ed. C. Guillot. Paris: Cahier d'Archipel, 25-33.

Thomaz, L. F. F. R. 1991. Nina Chatu and the Portuguese Trade in Malacca, trans. M. J. Pintado. Melaka: Luso-Malaysian Books.

Thurston, Edgar, and K. Rangachari. 1909. Castes and Tribes of Southern India. Madras: Government Press.

Tschacher, Torsten. 2001. Islam in Tamilnadu: Varia. Halle (Saale): Institut für Indologie und Südasienwissenschaften der Martin-Luther-Universität HalleWittenberg.

_. 2009. "Circulating Islam: Understanding Convergence and Divergence in the Islamic Traditions of Ma'bar and Nusantara." In Islamic Connections: Muslim Societies in South and Southeast Asia, ed. R. Michael Feener and Terenjit Sevea. Singapore: ISEAS Publishing, 48-67.

Wade, Geoff. 2010. "Early Muslim Expansion in South-East Asia, Eighth to Fifteenth Centuries." In Volume 3: The Eastern Islamic World Eleventh to Eighteenth Centuries, Vol. 3 of The New Cambridge History of Islam, ed. David O. Morgan and Anthony Reid. Cambridge: Cambridge University Press, $366-408$.

2012. "Southeast Asian Islam and Southern China in the Fourteenth Century." In Anthony Reid and the Study of the Southeast Asian Past, ed. Geoff Wade and Li Tana. Singapore: ISEAS Publishing, 125-45.

Wain, Alexander. 2015. "Chinese Muslims and the Conversion of the Nusantara to Islam.” Oxford University.

2017. "China and the Rise of Islam on Java." In Islamization: Comparative Perspectives from History, ed. A. C. S. Peacock. Edinburgh: Edinburgh University Press.

. 2020. "Southeast Asia." In The Oxford Handbook of Islamic Archaeology, eds. Bethany Walker, Timothy Insoll, and Corisande Fenwick. Oxford: Oxford University Press, 595-627.

Wilkinson, Richard James. 1901. A Malay-English Dictionary. Singapore: Kelly and Walsh Limited.

Winstedt, Richard. 1966. Hikayat Bayan Budiman, atau cherita Khojah Maimun. Kuala Lumpur: Malaya Publishing House. 
Yatim, Othman Mohd, and Abdul Halim Nasir. 2007. Epigrafi Islam Terawal Di Nusantara. Kuala Lumpur: Dewan Bahasa dan Pustaka.

Zhao, Rugua. 1966. Zhufan Zhi. Amsterdam: Oriental Press.

Zieseniss, Alexander. 1963. The Räma Saga in Malaysia, Its Origin and Formation. Singapore: Malaysian Sociological Research Institute.

Zoetmulder Petrus J., and Robson Stuart. 1982. Old Javanese-English Dictionary, $P$ - $Y$. Leiden: KITLV.

Alexander Wain, University of St Andrews, United Kingdom. Email: alexanderwain@hotmail.com. 


\section{Guidelines}

\section{Submission of Articles}

tudia Islamika, published three times a year since 1994, is a bilingual (English and Arabic), peer-reviewed journal, and specializes in Indonesian Islamic studies in particular and Southeast Asian Islamic studies in general. The aim is to provide readers with a better understanding of Indonesia and Southeast Asia's Muslim history and present developments through the publication of articles, research reports, and book reviews.

The journal invites scholars and experts working in all disciplines in the humanities and social sciences pertaining to Islam or Muslim societies. Articles should be original, research-based, unpublished and not under review for possible publication in other journals. All submitted papers are subject to review of the editors, editorial board, and blind reviewers. Submissions that violate our guidelines on formatting or length will be rejected without review.

Articles should bewritten in American English between approximately 10.000 words including text, all tables and figures, notes, references, and appendices intended for publication. All submission must include 150 words abstract and 5 keywords. Quotations, passages, and words in local or foreign languages should be translated into English. Studia 
Islamika accepts only electronic submissions. All manuscripts should be sent in Ms. Word to: http://journal.uinjkt.ac.id/index.php/studiaislamika.

All notes must appear in the text as citations. A citation usually requires only the last name of the author(s), year of publication, and (sometimes) page numbers. For example: (Hefner 2009a, 45; Geertz 1966, 114). Explanatory footnotes may be included but should not be used for simple citations. All works cited must appear in the reference list at the end of the article. In matter of bibliographical style, Studia Islamika follows the American Political Science Association (APSA) manual style, such as below:

1. Hefner, Robert. 2009a. "Introduction: The Political Cultures of Islamic Education in Southeast Asia," in Making Modern Muslims: The Politics of Islamic Education in Southeast Asia, ed. Robert Hefner, Honolulu: University of Hawai'i Press.

2. Booth, Anne. 1988. "Living Standards and the Distribution of Income in Colonial Indonesia: A Review of the Evidence." Journal of Southeast Asian Studies 19(2): 310-34.

3. Feener, Michael R., and Mark E. Cammack, eds. 2007. Islamic Law in Contemporary Indonesia: Ideas and Institutions. Cambridge: Islamic Legal Studies Program.

4. Wahid, Din. 2014. Nurturing Salafi Manhaj: A Study of Salafi Pesantrens in Contemporary Indonesia. PhD dissertation. Utrecht University.

5. Utriza, Ayang. 2008. "Mencari Model Kerukunan Antaragama." Kompas. March 19: 59.

6. Ms. Undhang-Undhang Banten, L.Or.5598, Leiden University.

7. Interview with K.H. Sahal Mahfudz, Kajen, Pati, June $11^{\text {th }}$, 2007.

Arabic romanization should be written as follows:

Letters: ', $b, t, t h, j, h, k h, d, d h, r, z, s, s h, s, d, t, z, ', g h, f, q, l$, $m, n, h, w, y$. Short vowels: $a, i, u$. long vowels: $\bar{a}, \overline{\mathrm{i}}, \overline{\mathrm{u}}$. Diphthongs: aw, ay. Tā marbūtāe $t$. Article: al-. For detail information on Arabic Romanization, please refer the transliteration system of the Library of Congress (LC) Guidelines. 
ستوديا إسلاميكا (ISSN 0215-0492; E-ISSN: 2355-6145) مجلة علمية دولية محكمة تصدر عن مركز دراسات الإسلام والمجتمع (PPIM) بجامعة شريف هداية الله الإسلامية الحكومية بجاكرتا، تعنى بدراسة الإسلام في إندونيسيا خاصة وفي جنوب شرقي آسيا عامة. وتستهدف المجلة نشر البحوث العلمية الأصيلة والقضايا المعاصرة حول الموضوع، كما ترحب بإسهامات الباحثين أصحاب التخصصات ذات الصلة. وتخضع جميع الأبحاث المقدمة للمجلة للتحكيم من قبل لجنة مختصة.

تم اعتماد ستوديا إسلاميكا من قبل وزارة البحوث والتكنولوجيا والتعليم العالي بجمهورية إندونيسيا باعتبارها دورية علمية (رقم القرار: 32a/E/KPT/2017).

ستوديا إسلاميكا عضو في CrossRef (الإحالات الثابتة في الأدبيات الأكاديمية) منذ ع ا • ب، وبالتالي فإن جميع المقالات التي نشرتا مرقمة حسب معرّف الوثيقة الرقمية (DOI). ستوديا إسلاميكا بجلة مفهرسة في سكوبس (Scopus) منذ .ب مايو 0 . ب.

$$
\begin{aligned}
& \text { قيمة الاشتر الك السنوي خارج إندونيسيا: }
\end{aligned}
$$

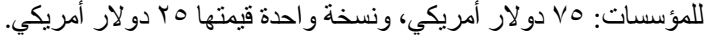

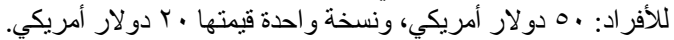

$$
\begin{aligned}
& \text { والقيمة لا تشمل نفقة الإرسال بالبريد الجوي. ونسي. }
\end{aligned}
$$

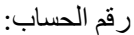

$$
\begin{aligned}
& \text { خارج إندونيسيا (دولار أمريكي): ابن }
\end{aligned}
$$

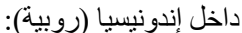

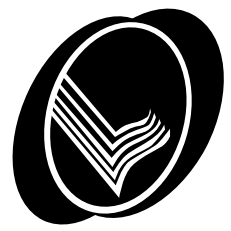




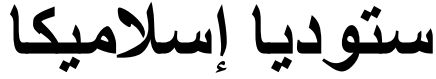 \\ مجلة إندونيسيا للار اسات الإسلامية

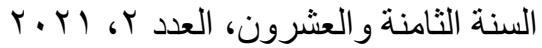

$$
\begin{aligned}
& \text { رئيس التحرير : } \\
& \text { أزيوماردي أزرا } \\
& \text { مدير التحرير: } \\
& \text { أومان فتح الرحمن } \\
& \text { هيئة التحرير: } \\
& \text { سيف المزاني } \\
& \text { جمهاري } \\
& \text { ديدين شفرالدين } \\
& \text { جاجات برهان الدين } \\
& \text { فؤاد جبلي } \\
& \text { علي منحنف جيفي } \\
& \text { سيف الأمم } \\
& \text { دادي دارمادي } \\
& \text { جاجانج جهراني } \\
& \text { دين واحد } \\
& \text { ايويس نورليلاواتي } \\
& \text { محمد قريش شهاب (جامعة شريف هداية الله الإسلامية الحكومية بجاكرتا) } \\
& \text { مارتين فان برونيسين (جامعة أتريخة) }
\end{aligned}
$$

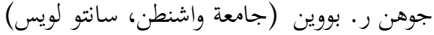

$$
\begin{aligned}
& \text { محمد كمال حسن (الجامعة الإسلامية العالمية - ماليزيا) }
\end{aligned}
$$

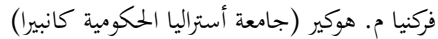

$$
\begin{aligned}
& \text { إيدوين ف. ويرنجا (جامعة كولونيا، ألمانيا) } \\
& \text { روبيرت و ـ هيفنير (جامعة بوستون) ويرنا }
\end{aligned}
$$

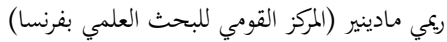

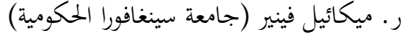

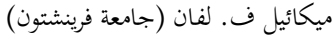

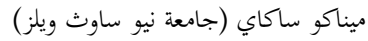

$$
\begin{aligned}
& \text { انابيل تيه جالوب (المكتبة البريطانية) } \\
& \text { شفاعة المرزانة (جامعة سونان كاليجاغا الإسلامية الحكومية) } \\
& \text { مساعد هيئة التحرير: - مسئ } \\
& \text { تيستريونو } \\
& \text { محمد نداء فضلان تئرنان } \\
& \text { رنغكا إيكا سافوترا } \\
& \text { عبد الله مولاني } \\
& \text { مراجعة اللغة الإنجليزية: }
\end{aligned}
$$

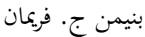

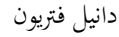

$$
\begin{aligned}
& \text { موسى بتول } \\
& \text { أحمدي عثمان }
\end{aligned}
$$





\section{لالتوايا السال|مسيا}




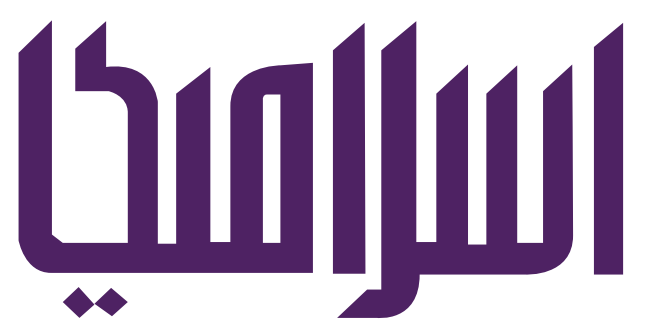

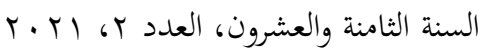

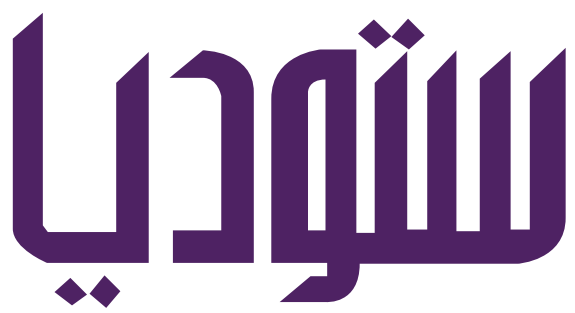

بحلة إندونيسية للدراسات الإسلامية

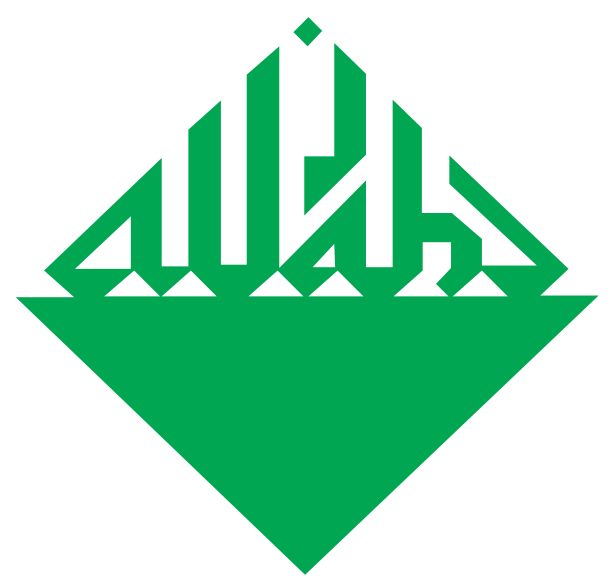

From Fiqh to Political Advocacy:

Muhammadiyah's Ecological Movement

in the Post New Order Indonesia

David Efendi, Nanang Indra Kurniawan, Purwo Santoso

Doing Hijrah Through Music:

A Religious Phenomenon

Among Indonesian Musician Community

Bambang Qomaruzzaman \& Busro

\section{اللغة العربية}

ثهيى المعاهد الإسلاهية بإنكونميسيا:

هشكلاتهما وطرةت حلهما

محمد نفيس جويني وأحمدي عثمان 